\title{
Gender Injustice in Compensating Injury to Autonomy in English and Singaporean Negligence Law
}

\author{
Tsachi Keren-Paz ${ }^{1}$
}

Published online: 22 November 2018

(C) The Author(s) 2018

\begin{abstract}
The extent to which English law remedies injury to autonomy (ITA) as a stand-alone actionable damage in negligence is disputed. In this article I argue that the remedy available is not only partial and inconsistent (Keren-Paz in Med Law Rev, 2018) but also gendered and discriminatory against women. I first situate the argument within the broader feminist critique of tort law as failing to appropriately remedy gendered harms, and of law more broadly as undervaluing women's interest in reproductive autonomy. I then show by reference to English remedies law's first principles how imposed motherhood cases-Rees $v$ Darlington and its predecessor McFarlane $\mathrm{v}$ Tayside Health Board - result in gender injustice when compared with other autonomy cases such as Chester $v$ Afshar and Yearworth v North Bristol NHS Trust: A minor gender-neutral ITA is better remedied than the significant gendered harm of imposing motherhood on the claimant; men's reproductive autonomy is protected to a greater extent than women's; women's reproductive autonomy is protected by an exceptional, derisory award. Worst of all, courts refuse to recognise imposed motherhood as detriment; and the deemed, mansplained, nonpecuniary joys of motherhood are used to offset pecuniary upkeep costs, forcing the claimant into a position she sought to avoid and thus further undermining her autonomy. The recent Singaporean case $A C B v$ Thomson Medical Pte Ltd, awarding compensation for undermining the claimant's genetic affinity in an IVF wrong-sperm-mix-up demonstrates some improvement in comparison to English law, and some shared gender injustices in the context of reproductive autonomy. $A C B$ 's analysis is oblivious to the nature of reproductive autonomy harm as gendered; and prioritises the father's interest in having genetic affinity with the baby over a woman's interest in not having motherhood imposed upon her.
\end{abstract}

Keywords Negligence - Actionable damage - Autonomy - Wrongful conception · Tort $\cdot$ Gender-based harm $\cdot$ Equality $\cdot$ Damages $\cdot$ Mansplaining

Tsachi Keren-Paz

t.keren-paz@sheffield.ac.uk

1 University of Sheffield, Sheffield, UK 


\section{Introduction}

Reproductive autonomy cases, especially wrongful conception, can be analysed through two analytical prisms. One is the feminist critique of reproductive law and family law (including access to abortion and constructions of motherhood) (e.g. West 1988, 1997; Bordo 2003; Siegel 2007; Cornell 1995; Priaulx 2007; Sheldon 2016; Sanger 2018) and of tort law, in particular, the inadequate remedying of gender-based harms (e.g. Chamallas 1998; Bitton 2010). A more specific literature criticises wrongful conception cases from a feminist perspective (e.g. Morris 2004; Priaulx 2007). The other and less obvious prism is a growing conversation on whether negligence law ought to and does compensate for undermining one's autonomy as a stand-alone head of damages (e.g. Nolan 2007; Clark and Nolan 2014; Purshouse 2015, 2017; Keren-Paz 2017, 2018).

The extent to which English law (and more generally the common law world) compensates injury to autonomy (ITA) as a stand-alone actionable damage in the tort of negligence is disputed. My interpretation of the relevant cases-Rees $v$ Darlington Memorial Hospital NHS Trust, ${ }^{1}$ Chester $v$ Afshar ${ }^{2}$ - Tracey v Cambridge University Hospitals NHS Foundation Trust, ${ }^{3}$ Shaw v Kovac, ${ }^{4}$ Yearworth $v$ North Bristol NHS Trust $t^{5}$ and Bhamra v Dubb $b^{6}$-is that English law does recognise injury to autonomy as actionable; however, it does so inconsistently. A look at the six most relevant appellate cases reveals that that they can be grouped into three categories: reproductive autonomy cases: Rees and Yearworth ${ }^{7}$; informed consent cases: Chester, Tracey and Shaw; and food consumption: Bhamra.

In this article, I would like to focus on the reproductive autonomy cases and argue that new insights could be gleaned by marrying the two analytical prisms-feminist critique of reproductive autonomy law and actionability of ITA - together. The analysis of Rees, and of its predecessor McFarlane $v$ Tayside Health Board Appellants ${ }^{8}$ reveals that not only the protection afforded in Rees to reproductive autonomy is inconsistent with recognition (or its absence) of ITA as actionable damage in other English cases (Keren-Paz 2018; cf. Keren-Paz 2007a, 2017) but that the holding undermines gender justice, is androcentric and is potentially discriminatory.

\footnotetext{
${ }^{1}$ [2003] UKHL 52.

2 [2004] UKHL 41.

3 [2014] EWCA Civ 822.

4 [2017] EWCA Civ 1028

5 [2009] EWCA Civ 37.

6 [2010] EWCA Civ 13.

7 The most important British reproductive tort case, dealing with wrongful conception, is McFarlane $v$ Tayside Health Board Appellants [2000] 2 AC 59 in which the upkeep costs of an unplanned daughter, fifth in the family, born due to negligent vasectomy, were denied and remedy was limited to the immediate costs (including pain and suffering) of the pregnancy and labour. Since a separate award for the undermining of reproductive autonomy was neither asked for nor awarded, I do not include McFarlane in the group of cases discussing ITA as actionable damage in negligence. But of course, it is indispensable as a reproductive tort case.

${ }^{8}$ Ibid.
} 
A general look at autonomy cases reveals that the most inadequate protection of ITAs relates to the category of reproductive choice, and more precisely, to wrongful conception. What accounts for this, beyond conceptual under-theorisation, is a normative difficulty: obliviousness to the nature of reproductive autonomy as a gendered harm. If this thesis is correct, the inadequate protection given to reproductive autonomy under Rees is the combination of both autonomy being a devalued protected interest (unorthodox, contested) and a devalued right-bearer-a fertile woman. This is emblematic of law's failure to adequately respond to women's experiences. I defend this view despite the fact that the only undisputed English case explicitly compensating ITA as actionable was in the context of failed sterilisation. ${ }^{9}$

As the discussion will reveal, Chester, Rees and Yearworth are problematic when looked upon in isolation and compared to each other. The protection afforded to ITA in these cases is patchy, inconsistent and under-theorised; the problems are both across categories of case law (mainly Chester and Rees) and within (mainly Rees and Yearworth). The conceptual deficiency, elaborated upon in Keren-Paz (2007a, 2017), lies in glossing over the crucial distinction between the three types of ITA: Type 1, being deprived merely of the opportunity to consent to being moved from one state of affairs to another (Chester and Tracey); Type 2, a more serious injury of being moved without consent to a subjectively inferior state of affairs (Rees, Yearworth and Bhamra); and Type 3, autonomy loss consequent upon violation of a previously protected interest (Shaw). This under-theorisation leads to inconsistent levels of protection both across and within categories and to an inverse hierarchy, according to which, more serious violations of ITA lead to lower damages awards and vice versa. Most troubling, perhaps, is the award of type 3 hefty damages (for the physical injury from the materialisation of the risk, deemed wrongly as a consequence of the interference with the claimant's autonomy) for type 1 (gender-neutral) ITA in Chester (depriving Chester of the opportunity to consent to submitting to treatment with its inherent risk, in circumstances she would have consented, had she been sufficiently informed), while at the same time awarding in Rees de facto type 1 damages (a flat conventional award reflecting the loss of notional control over reproductive autonomy) for very significant gendered ITA type 2 (the interference with the claimant's life plan from having an unplanned child) and type 3 (economic costs of raising an unplanned child which are a consequence of undermining the claimant's reproductive choice). This illustrates the shortcomings involved in the absence of joined-up thinking about the damage concept in law (in particular, negligence) and the casuistic stumbling from case to case, which is typical of wrongful conception cases (see Cane 2004; Priaulx 2017; McCandless 2017, 36).

Under-theorisation of ITA as actionable damage and gender injustice in reproductive autonomy cases is not unique to English law. ${ }^{10}$ I will demonstrate this with reference to the recent Singaporean Court of Appeal decision of ACB v Thomson Medical Pte $\mathrm{Ltd}^{11}$ in which loss of genetic affinity was recognised as actionable damage

\footnotetext{
9 See Keren-Paz (2018), for analysis of the six cases.

10 See Keren-Paz (2007a) for a critique of similar inconsistencies in early Israeli ITA jurisprudence.

11 [2017] SGCA 20.
} 
in a wrongful fertilisation case (which, I, and others (Fox 2017), see as a category of reproductive autonomy). ${ }^{12}$ The article concludes that while in certain aspects the decision is an improvement on Rees and McFarlane, ACB is marred as well by conceptual inconsistencies and obliviousness to the gendered nature of reproductive autonomy.

\section{Autonomy, Gender Justice and Gendered Harms}

Before delving into the analysis, a few related preliminary comments are in order: firstly, about the meaning of autonomy; secondly, the normative desirability of remedying ITA and thirdly, the meaning of gender justice and gendered harms. The starting point for my analysis is the understanding of personal autonomy as selfauthorship. This account, most forcefully developed by Joseph Raz, (and others e.g. Lindley 1986), is normatively attractive and influential in case law ${ }^{13}$ and legal scholarship (see e.g. Clark and Nolan 2014; Dagan 2013). According to Raz, 'the ideal of autonomy is that people should make their own lives' and the 'autonomous person is a (part) author of his own life... the vision of people controlling, to some degree, their own destiny, fashioning it through successive decisions throughout their lives' (1988, 155-156).

The standard, liberal account of autonomy, at least as applied to tort law, focuses on the ability to make choices simpliciter (see e.g. Cane 1997, 234; cf. DanCohen 2002, 125). However, it is debated whether the ideal of self-authorship can be invoked to trigger a private law remedy for any setback to one's choices and desires. To use the terminology of feminist philosopher Diana Meyers, it is unclear whether we ought to remedy violations of episodic autonomy, as opposed to programmatic autonomy $(1987,624-625) .{ }^{14}$ Arguably, Raz's own conception of autonomy as self-authorship could be understood as programmatic rather than episodic (choice-centred). Remedying ITAs that undermine deeply held values-in which the choices undermined are positioned on the continuum somewhere between episodic autonomy, reflecting 'thoughtless desire' (Frankfurt 1971), and programmatic

\footnotetext{
12 While I have written on reproductive autonomy in the past-in the context of women's duty of care to their born alive child for prenatal injuries (Keren-Paz 2005, 2007b), the genealogy of this paper has to do with my interest in ITA as actionable in negligence. As such, $A C B$ 's overt discussion of whether the harm has to be compensated as an ITA made it appropriate to examine $A C B$ against the line of cases of ITA as actionable damage and (as does Fox (2017)) wrongful conception. Having said this, $A C B$ could be examined against another line of cases dealing with mistakes relating to gametes. Some of the similarities and differences between these categories of cases are examined in the last part of the paper, but I leave a full discussion of these issues for another day, including what interests, other than autonomy, are implicated by confounded procreation cases.

13 Coleman v Attridge Law (A Firm) (C-303/06) [2008] All ER (EC) 1105 [9]; CA 10064/02 Migdal v Abu Hannah, PD 60(3) 13 (Supreme Court, ISr, 2005) [33].

14 A person is programmatically autonomous when she is carrying out a life plan (how do I want to live my life?) that embodies her own answers to a particular type of question (what kind of work do I want to do; do I want children? etc.). In contrast, episodic autonomy entails being able to ask "what do I really want to do now?' in a given situation.
} 
autonomy - protects the core of self-governance, ${ }^{15}$ so that "people can freely make up their own minds about what to believe and how to live, and can then act accordingly' (Voorhoeuve 2009). Similarly, if the effects of the thwarted choice are significant or lasting, they are more likely to affect programmatic, rather than episodic, autonomy.

The liberal notion of autonomy has been criticised from communitarian, feminist and critical quarters as ontologically and normatively deficient (e.g. MacIntyre 1984; Hoagland 1988; Althusser 1976, 205; O’Shea 2012; West 1988; Bordo 2003; and in the context of wrongful conception, Priaulx 2007). Alternative understandings of 'relational' and 'embodied' autonomy have thus been offered (Christman 2004; Oshana 2006; Cowan 2007). At first glance, such a critique might query the desirability of remedying ITA in negligence-perhaps especially from a feminist perspective - and raises the question of the threshold for injuries that ought to be compensated. I have recently normatively defended remedying ITA in negligence and would not repeat the argument here. A remedy for type 2 ITA is justified if the choice that was undermined was based on deeply held views or pertained to core issues with respect to which self-authorship is especially important. Since a constitutive element of type 2 ITA is the undermining of the claimant's reliance interest, a remedy in negligence (and not only in contract) is called for. Where the choice undermined pertains to a sufficiently important interest, such as determining what treatment to receive, even type 1 injuries ought to be compensated (Keren-Paz (2017)).

Currently, I would make four points. First, even in feminist and critical quarters, the implications of the critique of the liberal conception of autonomy for consent and choice are unclear (Hunter and Cowan 2007; Nedelsky 1989; West 1988). In particular, the notion of embodied autonomy developed mainly in the critique of rape law (e.g. Cowan (2007)) seems to be quite apt in wrongful conception cases, which are a major category of reproductive autonomy cases. Put differently, whether one adopts a classic, thin, liberal conception of choice, or a thicker one, protecting significant choices, the pattern of decisions analysed below remains inconsistent and hard to justify. The thicker notion, which I support, is identical or very similar to relational or embodied concepts of autonomy. Bordo (2003, 94), for example, calls to shift the feminist reproductive rights discourse 'from abstract rhetoric of choice' to 'insisting that women's equal protection' requires resolving 'contradictions... regarding' the extent of protecting 'bodily integrity' and 'reclaiming... pregnancy and abortion as experientially profound events'.

Second, the thicker notion of autonomy I adopt-protecting choices that are informed by one's personal beliefs, ethics, values, attitudes and world view, or which have a significant bearing on the way one leads one's life-is immune to much of the critique uttered against the narrow liberal conception and is likely to assuage fears about the negative practical and expressive ramifications of compensating individuals in negligence for thwarted choices. Put differently, even if compensating Bhamra-like cases (unwittingly consuming food, undermining one's ethical beliefs

\footnotetext{
${ }^{15}$ See Chico $(2011,66)$, based on the influential accounts of Gerald Dworkin and Harry Frankfurt.
} 
or in contrast to one's religion) is contested, compensating a woman for negligently imposing motherhood upon her ought not be. The point will become clearer in the following discussion of gender justice and gender harms. For now, I will only note that Raz's account of autonomy as authorship, which underlies my account of remedying ITA, seems to be endorsed by Reva Siegel $(2007,816)$ and Carol Sanger $(2018,37)$ in their call to further women's reproductive autonomy. Thus Siegal cites approvingly the unmistakably Razian formulation adopted in Planned Parenthood of Se. Pa. v. Casey ${ }^{16}$ as the basis to critique states' intervention in women's reproductive autonomy as undermining women's equality: 'The destiny of the woman must be shaped to a large extent on her own conception of her spiritual imperatives and her place in society.' Sanger too acknowledges that control over reproductive plans is connected 'to the idea of autonomy, in the sense of vindicating a person's selfauthorship of his of her life' citing Raz, and that 'this idea is already vindicated in the abortion jurisprudence'. It is true that Sanger entertains doubts on whether control is the useful framework for reproductive torts as part of her critique of Dov Fox's framing of the issue (2017). However, I read her claim that the gist of the harm in reproductive torts (pace Fox) 'is not the loss of control over planning but rather, the loss of what the plan meant to produce' as entirely compatible with the two claims I make in this article. First is the analytical distinction between type 1 injury (being deprived merely of the opportunity to consent to being moved from one state of affairs to another) and type 2 injury (involving a consequential loss from being moved without consent to a subjectively inferior state of affairs). Second is the normative claim that given the far-reaching consequences of interferences with reproductive autonomy, such interferences should be remedied by much higher damages than those given for gender neutral type 1 injury (as in Chester). Sanger also seems to endorse the autonomy framework as 'perhaps running in parallel' to focusing on remedying the emotional harms of disappointed expectations in the reproductive context and on recognising pregnancy itself as an injury.

Likewise, my endorsement of a thick conception of choice, and the importance of protecting it, while being critical of the thin impoverished notion of choice, is aligned with Priaulx's (2007) analysis of wrongful conception. Indeed, as I have explained in my review of her book 'Insisting that women suing for wrongful conception still have choice, albeit a difficult one, while clarifying that the defendant's liability should be grounded in the fact that it subjected the woman to such a difficult choice-by reducing the range of options open to the claimant-is, to me, Priaulx's most significant contribution in the book.' (Keren-Paz 2008).

Third, especially since courts' liberal commitment is with us to stay, we should develop the jurisprudence in a way that is not androcentric and discriminatory (Keren-Paz 2013, 145). Finally, even on its own terms of a liberal, thin conception of choice, the pattern of decisions does not make sense (although the decision to view ITA as actionable negligence does), a point I develop at the end of the next section while explaining the inconsistency between Rees on the one hand, and Chester or Yearworth on the other.

16 505 U.S. 833, 852 (1992). 
Reproductive torts invoke autonomy in the contexts of gendered harms and gender justice. Gendered harms are suffered either uniquely or disproportionately by one gender, and the extent to which gendered harms are adequately addressed by law (including tort law, which focuses on redressing wrongful harms) is a major part of any gender-justice inquiry. In the context of tort law, gender injustice might result from application of seemingly equal rules to facially non-gendered harms by ignoring background conditions which disadvantage women. An example would be rules of compensating lost earnings for personal injury which perpetuate and at times exacerbate women's reduced income in the labour market (see Chamallas and Wriggins 2010). Alternatively, as in the case of reproductive torts or sexual abuse, gendered harms typically suffered by women are devalued (in different areas of the law including tort, criminal, family and constitutional law) in ways which are either outright discriminatory or otherwise problematic, by failing to take on board women's interests, morality and epistemology. ${ }^{17}$

The analysis of wrongful conception (and more broadly reproductive autonomy/ torts) offered here chimes with the following: (1) Realisation that the stakes of denying reproductive choices, especially for women, are enormous. ${ }^{18}$ This translates to criticising the very limited remedy offered in Rees and to the inconsistent level of protection in comparison to Chester. (2) The harm in reproductive torts is mainly non-material and involves the undermining of decisional autonomy and its far-reaching consequences, including, in particular, women's personhood, subjectivity and citizenship. ${ }^{19}$ As such, redress is called for not only as a matter of autonomy but also of well-being (Fox $(2017,177)$; Sanger $(2018,36)$ ). This translates to the need to recognise autonomy (at the very least reproductive autonomy) as actionable in negligence and the importance of distinguishing between types 1, 2, and 3 ITA. Indeed, Sanger's critique of Fox's conceptualisation of the harm ${ }^{20}$ becomes more intelligible once the distinction between the mere undermining of decisional autonomy in type 2 cases and its consequences is well understood (Keren-Paz 2017, 420-421). ${ }^{21}$ (3)

\footnotetext{
17 See in the contexts of: sexual harassment Bernstein (1997); image-based abuse McGlynn and Rackley (2017); reproductive autonomy West (1988, 1997); Bordo (2003); Priaulx (2007); Sanger (2018, 39-45) who notes (at 40) that 'the measure of disappointment' from 'losing control over reproductive plans' 'is not gender neutral'.

18 See West (1988, 30-32, 41 (being 'overtaken, occupied, displaced and invaded', 47 (compulsory motherhood as 'tremendously constraining, damaging and oppressive'); Bordo (2003, 93) (constraining women reproductive choices challenges 'women's status as subjects'); Siegel (2007, 819) (highlighting 'both practical and dignitary significance to the decisional control that reproductive rights afford women'); Priaulx (2007).

19 Siegel (2007); Bordo (2003, 77 (women as fetal containers, see also Annas (1986)), 85, 93 (threat to women's subjectivity); West (1988, 1997, 107); Sanger (2018); Priaulx (2007).

20 Sanger $(2018,36)$ who describes Fox's conceptualisation as focusing on 'disruption to an individual's procreative plans' as opposed to Sanger's suggestion that it 'is not the loss of control over planning but rather, the loss of what the plan meant to produce' that matters. I think that Sanger misreads Fox, in this regard, as he is very clear throughout, that the harm in such cases is much about the consequences (and hence implicates women's well-being), a point which is also reflected in his sketch of damages quantification.

21 See also Keren-Paz $(2018,418)$ for the similar distinction between simultaneously suffering ITAs 2 and 3 .
} 
Reproductive autonomy is a matter of sex equality (equal protection in US constitutional terminology) and not only of liberty or privacy (Bordo 2003; Siegel 2007; Cornell 1995). Hence, the focus on the discriminatory aspects of the limited protection reproductive autonomy received in Rees and in $A C B$ and on viewing cases of imposed procreation (to use Fox's terminology), such as Rees, as deserving stronger remedy than confounded procreation, such as $A C B$.

\section{Five Aspects of Gender Injustice in English Wrongful Conception Cases}

Reproductive autonomy is gendered; negligent undermining of reproductive autonomy is a gender-based harm disproportionately harming women. This feature, beyond the conceptual under-theorisation discussed above, helps explain why the protection of autonomy in English negligence law is unsatisfactory. This reading of Rees focuses, therefore, on its nature as a reproductive autonomy case, while the analysis in Keren-Paz (2018) highlighted its nature as an autonomy case. If this thesis is correct, the flimsy protection given to reproductive autonomy under Rees is the combination of both autonomy being a devalued protected interest/actionable damage (unorthodox, contested) and a devalued right-bearer-a fertile woman.

In Rees, the claimant wished not to have children (mainly due to the fact that she had a genetic condition that rendered her practically blind). She underwent a sterilisation operation, which was conducted negligently, so unbeknown to her had failed. She eventually became pregnant and gave birth to a son. The House of Lords awarded $£ 15,000$ as a conventional award to compensate the claimant for her loss of reproductive autonomy not to become a parent.

Rees results in gender injustice. The first and most troubling aspect of gender injustice in wrongful conception cases is courts' refusal to legally acknowledge that unwanted motherhood is a 'detriment'. The original sin lies with McFarlane, not Rees, although as evident from reading McFarlane, its reasoning reflects commonly held views among judges across many jurisdictions. Such a view is based on 'what is morally acceptable and what is not' lest:

parents may be put in a position of arguing in court that the unwanted child, which they accepted and care for, is more trouble than it is worth ... the law of tort has no business to provide legal remedies consequent upon the birth of a healthy child, which all of us regard as a valuable and good thing. ${ }^{22}$

The 'law must take the birth of a normal, healthy baby to be a blessing, not a detriment.' While individuals 'may choose to regard the balance as unfavourable ... society itself must regard the balance as beneficial'. ${ }^{23}$

This normative stance forces parental obligations (which are clearly gendered) on the mother-epitomising Robin West's broader observation that ' $[\mathrm{M}]$ ost women are

\footnotetext{
22 Supra $\mathrm{n} 7$ at 82 (Steyn).

23 Ibid at 114 (Millett).
} 
indeed forced into motherhood' (1988, 71) — and is, therefore, at odds with sociological, psychological and political science findings about the costs of motherhood (let alone of an involuntary one). Ruth Cain (2007) highlighted both the difficulties embedded in motherhood in different social contexts and the opprobrium faced by mothers who dare to complain about mothering. Orna Donath's study (2015) amply documents the biggest taboo of all: 'regretting motherhood'; the study critically examines the cultural narration of adapting to motherhood, of which McFarlane's rhetoric is a good example. Data also exists on the specific costs of unwanted motherhood; compared with having an abortion, being denied one may be associated with a greater risk of initially experiencing adverse psychological outcomes (Biggs et al. 2017).

McFarlane's endorsement of forcing parental obligations on the mother is incompatible with the normative disapprobation - in both philosophy and law, and especially at common law_of positive duties. It barely needs mentioning that in negligence law itself, there is no duty to rescue, and denying the mother recourse against the negligent defendant in wrongful conception cases amounts to the imposition of such a duty. This argument is well developed in the context of the right to abortion (see Thompson 1971; Bernstein 2016, 2018), but is equally valid as a reason to support a duty of care in wrongful conception cases.

The second aspect of gender injustice (but perhaps also of the flawed conceptualisation of ITA) is the denial of upkeep costs on the grounds that the parents bear the joys of parenthood so cannot expect the defendant to bear the financial costs. This argument was presented in McFarlane as a matter of fairness ${ }^{24}$ and in other jurisdictions (notably, but not only, in the USA) as a matter of offsetting benefits. ${ }^{25}$ In conceptualising ITA we need to distinguish 'between loss of autonomy resulting from any duty to pay for the unsolicited benefit, and loss flowing from the fact that the claimant's actions in conferring what the market might regard as a "benefit" have put the defendant in a position that is subjectively inferior to his pre-interference condition' (Keren-Paz 2017, 423). The general rule within restitution law is that unsolicited benefits which were not freely accepted do not give rise to a duty to make restitution. ${ }^{26}$ For this reason, when the tortious act also conferred a benefit on the claimant, offsetting the benefit is not automatic and straightforward. If a set-off is allowed, the claimant is subject to the defendant's power to force on the claimant a transaction in which the improvement to one interest is financed by the diminishment of another interest. In order to prevent this danger, one of the conditions in $\$ 920$ of the Restatement (Second) of Torts for allowing set-off is that the benefit is to the same interest undermined by the breach of duty. Only when this is the case does the offsetting not involve a forced transaction on the claimant. Pace Lord Millett in McFarlane, who commented that the claimants could not be allowed 'by a

\footnotetext{
${ }^{24}$ McFarlane supra $\mathrm{n} 7$ [97] (Lord Hope) (and cf [105] (Lord Clyde), [113] (Lord Millett)).

25 See e.g. Custodio v Bauer, 59 Cal Rptr 463 (1967).

26 Benedetti v Sawiris [2013] UKSC 50 [18] with explicit reference to 'the fundamental need to protect a defendant's autonomy'. As discussed in the next section, even those denying remedy for wrongful conception largely recognise that accepting an unwanted child is not free, given the moral, sociological and psychological costs of abortion or adoption.
} 
process of subjective devaluation, to make a detriment out of a benefit', ${ }^{27}$ the refusal to allow subjective devaluation in wrongful conception cases seems unprincipled and possibly discriminatory. ${ }^{28}$

Denying a claim based on the parent's accepting the child into the family is also incompatible with the modern near impossibility to establish the volenti defence in negligence and with the requirement that the claimant will consent to the risk of not being compensated, rather than to the risk of injury. ${ }^{29}$ By analogy, accepting parental obligations towards the unplanned child does not mean waiving the claim against the defendant.

The third and related aspect of gender injustice in wrongful conception cases is the use of distributive justice considerations — of fairness (Keating 2000) and equality (Keren-Paz 2007b) - to justify the denial of the claimants' costs of raising an unplanned child. ${ }^{30}$ This ignores the obvious relevance of distributive justice, here gender justice, to adequately compensate for loss of reproductive autonomy, which is a gendered harm. As feminist thinkers have demonstrated, and was summarised above, this is symptomatic of law's broader failure to understand what is at stake in denying women reproductive autonomy and, even more broadly, to take women's experiences, morality and epistemology into account. The autonomy loss is likely to be much less wealth dependent than the costs of raising a child and for this reason too, compensating it is normatively desirable.

The one qualification to this statement is that the mother's career loss from having the unplanned child might have a socio-demographic gradient. Women in well-paid jobs might feel that the setback to their career is more significant. But here, too, care should be taken to distinguish between the pecuniary and non-pecuniary aspects of the career setback. The long-term reduction in earnings due to care responsibilities is unrecoverable, according to Greenfield v Irwin. ${ }^{31}$ But the fact that the claimant's career was interfered with and, as a consequence, she is less able to feel fulfilment and satisfaction, are exactly part of what an award for type 2 autonomy loss is meant to compensate. As long as restitutio in integrum is the controlling remedial principle in private law, notwithstanding its built-in regressive effects (Abel (1990)), it will be most untoward to deny compensation for autonomy loss that is distinctively gendered in order to avoid disproportionate compensation of the better-off (cf. KerenPaz (2007b, 149, 175); Keren-Paz (2013, 145)).

\footnotetext{
27 Supra $\mathrm{n} 7$ at 112.

${ }^{28}$ It is beyond the scope of this article to provide a comprehensive examination of the extent to which restitution law's autonomy preserving principles of free acceptance and incontrovertible benefit are or ought to be adopted for purposes of setting off benefits against the harms in torts damages. It suffices to say, that, as indicated in the text, the Restatement's doctrinal requirement of 'same interest' as a condition for such set-off advances the same value enshrined by the free acceptance requirement.

29 Nettleship v Weston [1971] 2 QB 691.

30 McFarlane supra n 7 [83] (Lord Steyn), [91] (Lord Hope) (regressive result argument); see supra, n 24 (fairness argument). To be sure, there is similarity between the fairness argument and the 'moral repugnancy' argument discussed above-that parental obligations cannot normatively be considered as a loss. But I believe that the arguments are different, so even if upkeep costs could be considered as loss, there might still be policy reasons against compensating claimants for that loss.

31 [2001] 1 WLR 1279.
} 
Compensating autonomy loss is still subject to the same fairness argument mounted against compensating upkeep costs. Since the parents bear the joys of parenthood they should bear the autonomy loss. ${ }^{32}$ But, of course, the set-off argument itself is oblivious to the value of autonomy. It is not for the defendant to force an unwilling claimant to become a parent and set off from the autonomy loss created by its negligence the joys of parenthood, which the claimant explicitly sought to avoid. $^{33}$

Finally, note also the ironic reversal of the fairness claim in McFarlane-that it is unfair that the parents who enjoy the child will not bear the costs of its upbringing. ${ }^{34}$ Denying the right to damages from wrongful conception claimants based on the social value of the family unit, ${ }^{35}$ amounts to a form of taking, or expropriation without adequate compensation, and is, therefore, problematic on fairness grounds. The reluctant parents are required to discharge obligations they sought to avoid and are denied compensation due to a belief that such compensation will undermine a socially valuable institution.

In theory, an award for undermining the parents' reproductive autonomy could be given in addition to upkeep costs. ${ }^{36}$ Having an unplanned child creates both pecuniary and non-pecuniary costs and, as we have seen, the policy considerations for and against awarding them are quite different. Pecuniary costs have a wealth gradient (rich parents are likely to recover more) and are largely not gendered ${ }^{37}$; non-pecuniary costs, i.e. autonomy loss, have the reverse pattern.

Historically, the conventional award was probably developed as a consolation prize' given the refusal to award child-rearing costs. The Law Lords might have felt that sending the claimant away empty-handed was inappropriate. It should also be recalled that the claimants did not plead compensation for their autonomy loss (which is unsurprising given the fact that this interest was not traditionally protected by the tort of negligence). But now that the interest has been recognised (Nolan 2007, 73-77), and even more, (as discussed below) given the award of type 3 damages to type 1 injury in Chester, it is time to protect the interest in reproductive autonomy in a more principled and comprehensive manner.

A fourth aspect of gender injustice is manifested in Lord Millett's insistence that the award be given in equal share to both parents. ${ }^{38}$ This is odd. While unplanned parenthood significantly undermines the father's autonomy, it typically undermines much more the mother's for the following reasons: childcare is still overwhelmingly

\footnotetext{
32 Supra 24.

33 See text to supra $\mathrm{n} 26$.

34 See supra $\mathrm{n} 24$.

35 See especially Lord Millett's view cited in supra n 23; cf. references in ACB supra n 11 [92] to the family being 'the basic unit of society'.

36 This would be the equivalent of awarding type 2 and type 3 damages cumulatively, a debated possibility in Israeli case law. See Keren-Paz (2018), n 108.

37 However, since there are more women than men in single-parent families the pecuniary loss is somewhat gendered. Indeed, there is much to be said for allowing child-rearing costs in cases where the patient is a single parent, who is typically on quite a low income (cf. Amirthalingam 2018, 17).

38 Rees supra $\mathrm{n} 1$ [124].
} 
performed by women (Graycar and Morgan 2002, 267; Schober 2010, 13-22); social construction of parents' roles is gendered (Sanchez and Thomson 1997, 748-749; Bass 2015, 364-365); the relative importance associated with one's role as a parent vis-à-vis other social roles is likewise gendered (Thompson and Walker 1989, 864; Nilsen et al. 2013, 134-135). In a sense, Millett's obliviousness to all this is just another manifestation of the problem, which is discussed immediately below, of compensating type 2 injuries by means of a conventional award. After all, the interference with reproductive autonomy is likely to cause different quanta of losses to different women. However, in theory, one could come up with two gendered conventional awards with different sums, reflecting the unequal distribution of childcare responsibilities with their corresponding effect on autonomy (cf. West 1988, 31; Priaulx 2007; Sanger 2018, 40). So, the problems are, in fact, separable.

The fifth aspect of gender injustice is the deviation from the principle of full compensation and the setting of a very low amount for the conventional award. This is problematic both in itself and compared to Chester and Yearworth.

\section{Chester and Rees: Wrongly De-prioritising Type 2, Gendered, Injury}

In Chester, Afshar negligently failed to warn Chester of a small inherent risk in the procedure she undertook and the risk materialised. There was no negligence in the way the procedure was undertaken and, had Chester been warned, she would have delayed her consent but eventually would have undergone the procedure. Despite the fact that the breach of duty-the failure to inform Chester of the risk-did not increase the chance that the injury would materialise, Chester was fully compensated for the consequent physical injury in order to vindicate her interest in autonomy. ${ }^{39}$

Taken together, the holding in Rees and Chester raises three problems. ${ }^{40}$ First, a conventional award in Rees is a deviation from the principle of full compensation and, as such, is inconsistent both with Chester and with the rest of English remedies law. Leaving aside this inconsistency, one might still doubt whether the award to all mothers in wrongful conception cases should be standardised, ignoring important differences between them. For one thing, the motivation for not wishing to have a child might have a bearing on the significance of the intrusion (cf. Fox 2017; Purshouse 2017). For example, thwarting a financially motivated decision seems less intrusive than thwarting a motivation to avoid the burden of raising children. ${ }^{41}$ And of course, individual circumstances will influence the 'opportunity cost' of having an unplanned child. For example, the effect of the caring responsibility on the mother's educational and career choices would differ (and depend also on her age,

\footnotetext{
39 Chester supra n 2 at [86] (Lord Walker); [16] (Lord Steyn); [22] (Lord Steyn); [55] (Lord Hope); [87] (Lord Hope); cf. at [24] (Lord Steyn) and [101] (Lord Walker).

40 For a fuller analysis see Keren-Paz (2018).

41 See Bevilacqua $v$ Altenkirk [2004] BCSC 945 in which the different parents' motivations led to an award of $\$ 30,000$ to the mother and $\$ 20,000$ to the father.
} 
socio-demographic background and available support). A conventional award does not accommodate any of these factors. ${ }^{42}$

Secondly, Rees is also conspicuous for the paltry amount given as compensation (or vindication). This is problematic. ${ }^{43}$ The injury in Rees ought to be considered at the higher end of violation of one's autonomy in terms of the context (reproductive autonomy, which raises issues of sex equality) and its long-lasting and ever-present consequences. ${ }^{44}$ The idea that $£ 15,000$ is sufficient to either vindicate the claimant's choice not to become a parent, or to compensate her for the profound effects of this intrusion on her life is shocking indeed.

Thirdly, Chester erred by giving in effect a type 3 damages (for physical injury) for a type 1 injury (loss of opportunity to consent which would have been given had it been asked): As a type 1 injury, damages should be on the lower side of the spectrum since the claimant would have conceded to undergo the procedure with the associated risk. This means that (1) there is no causation between the breach of duty to disclose the risk and the physical injury and (2) the ITA itself is less serious than in type 2 cases (a subjectively inferior state of affairs post intervention), in which the choice is more significant. After all, in type 2 the claimant would not have agreed to be moved from the pre-intervention to the post-intervention state of affairs, while so agreeing (had she been asked) in type 1.

Taken together, then, Chester awarded type 3 damages for a type 1 injury, i.e. where the breach of duty did not cause the physical injury in seemingly a non-gendered context of informed consent. ${ }^{45}$ In contrast, Rees failed to award type 3 damages (upkeep costs and forgone income in the labour market as a result of caring responsibilities) and, in addition, failed to give full compensation for ITA type 2 (undermining the claimant's life plan by thrusting motherhood upon her). By this, it devalued perhaps the most significant type 2 injury (forced motherhood) by giving in effect a type 1 remedy (for the notional undermining the claimant's reproductive autonomy), which is both of exceptional nature (a conventional award) and extraordinarily low. ${ }^{46}$ If at all, type 1 injury (as in Chester) is more amenable to a conventional award, since claimants in this category complain only of the fact that they were deprived of the possibility to say yes, not of being subject to an inferior state of affairs, where harm will naturally vary from one claimant to another.

\footnotetext{
42 A point lost on LJ Davies in Shaw supra $\mathrm{n} 4$ [72].

43 For critique see e.g. Priaulx (2007, 73-76); Morris (2004, 16). For an understanding of the award as vindication see Wilcox (2012, 405); Varuhas (2014, 269-270).

44 Both aspects were documented above in the gendered harms section.

45 It is possible, however, that even outside of the reproductive context, there is still a gendered pattern of breaching more often the duty to attain female patients' informed consent. Cf. Keren-Paz (2007a, 228-235), examining the desirability of type 1 damages awards from an egalitarian perspective.

46 These two critiques should be distinguished. A significantly higher conventional award could have better reflected the profound undermining of such a fundamental aspect of one's autonomy but would still be of an exceptional nature and fail to cater for the different effect of forced motherhood on different claimants.
} 


\section{Rees and Yearworth: His and Her Reproductive Autonomy Awards?}

A look at the two reproductive autonomy cases—Rees and Yearworth-reveals quite a different treatment of ITA (cf. Koenig and Rustad 1995). In Yearworth $v$ North Bristol NHS Trust, damages for mental distress were held to be available (subject to proof of factual causation) as a consequence of learning that the claimants' sperm had been negligently destroyed by the defendant, which had undertaken to look after the claimants' sperm with all possible care. The court based this conclusion on two factors: (1) characterising the relationship between the claimants and defendant as gratuitous bailment; and (2) the applicability to bailment of contractual damages for mental distress in cases where an object of the contract was to provide peace of mind. ${ }^{47}$

As I explain in Keren-Paz (2017), despite facially being a type 3 (mental injury consequent on property loss), type 2 is the more accurate classification. The nub of the litigation was the lost chance to become a father (and the fear resulting from that loss, even if the claimant subsequently regained fertility), which is clearly a type 2 injury related to one's reproductive autonomy. Indeed, the court itself understood the claim in this way, by noting that the purpose of the arrangement was 'the provision to the men of non-pecuniary personal or family benefits. Any award of damages should reflect the realities behind these arrangements and their intended purpose'. ${ }^{48}$

The defendant's breach of duty in Yearworth obviously interfered with the reproductive autonomy of those claimants who did not regain their fertility. There is much to be said (on grounds of consistency) for the applicability of the conventional award in Rees, irrespective of the availability of damages in bailment for mental distress. Elsewhere (Keren-Paz 2018), I have noted five issues to be resolved in terms of examining the consistency between the two cases. Here, I will focus on those implicating gender justice: (1) whether a remedy for the ITA should accumulate (in both cases) with damages for mental distress — otherwise, it seems that men's interest in reproductive autonomy is protected to a greater extent than women's; (2) whether a standalone remedy for undermining reproductive autonomy (as distinct from damages for mental distress) should be a conventional award (to be consistent with Rees) or adhere to the principle of full compensation (given the critique offered above of the conventional award); and (3) how, ideally, the quantum for ITA in Yearworth (foregone fatherhood) should compare with that of Rees (imposed motherhood).

Could the claimants recover for both ITA and psychiatric injury or distress? It is useful to distinguish between different groups of claimants. Firstly, there are claimants who did not regain fertility, who ought to recover for ITA even if they did not suffer psychiatric injury (or even distress, if ITA is to be measured

\footnotetext{
47 Yearworth supra n 5 [49, 56-58].

48 Ibid [57] (my emphasis). The care the court took to analyse the Human Fertilisation and Embryology Act 1990 also supports this conclusion. But for current purposes, not much hangs on accepting as correct my claim that the court itself viewed the claim in Yearworth as based on ITA 2. What matters is that the case ought to be understood as protecting reproductive autonomy, and hence be condemned for the ensuing inconsistencies with Rees.
} 
irrespective of the distress it causes ${ }^{49}$ ); otherwise, the type 3 award in Yearworth is under-inclusive. ${ }^{50}$ Secondly, claimants who suffered psychiatric injury ought to be compensated for that loss. Crucially, to be non-discriminatory, such entitlementwhich to be recalled is extended also to those suffering merely mental distress falling short of psychiatric injury-should inhere with Rees-like claimants. ${ }^{51}$ This is especially so, given the enormity of harms stemming from forced motherhood, the judicial tendency to misunderstand or belittle these harms and the need to respect reproductive rights in a manner consistent with sex equality, as discussed above.

While the McFarlane court refused to normatively view unplanned motherhood as detriment, there is evidence suggesting that postpartum depression is more likely when the child is unplanned (Biggs et al. 2017). Surely, the decision in Yearworth commands that the actual costs of postpartum depression should be remedied without being capped by the $£ 15,000$ conventional award. As Bauer et al. $(2014,4)$ have found, the average cost to society of one case of perinatal depression is around $£ 74,000$, of which $£ 23,000$ relates to the mother and $£ 51,000$ relates to impacts on the child. ${ }^{52}$ However, if imposed motherhood is normatively deemed to be a joy ${ }^{53}$ (to the extent it is used to offset upkeep costs) what normative space is left to compensate mothers for the distress or, at times, postpartum depression which follows imposed motherhood?

The second issue raises an important and general jurisprudential question of the relationship between coherence and justice. Both Rees- and Yearworth-like claimants should receive full compensation for the interference with their reproductive autonomy. To the extent that a standalone ITA award in Yearworth would have been set above $£ 15,000$ while the Rees limitation stands, I would see this as problematic as both inconsistent and based on feminist critique of devaluing women's interests (West 1988, 1997; Siegel 2007; Priaulx 2007). Indeed, that the actual award the claimants in Yearworth are likely to receive far exceeds $£ 15,000$ is problematic in terms of gender equality. This relates to the last issue that, in applying Rees, one needs to decide whether interference with reproductive autonomy by denying parenthood is more, less or as serious as an interference imposing parenthood. One also needs to decide whether these harms are gendered and, if so, whether this ought to be reflected in the size of the award. These questions have to be answered, even if the decisions in Rees and Yearworth are corrected, so that all types of interference

\footnotetext{
49 Space constraints do not allow discussing this important point. An analogy to Gulati v MGN Ltd [2015] EWHC 1482; aff'd [2015] EWCA Civ 1291 (CA) might suggest a positive answer. Israeli courts are in disagreement. See also (in a type 1 context) Keren-Paz (2007a, 198-200).

${ }^{50}$ Claimants who suffered psychiatric injury, from the belief they would not be able to father children, prior to regaining fertility, who therefore did not suffer permanent ITA, should also be compensated.

51 In wrongful conception cases, mental distress occasioned on the pregnancy and birth (as opposed to rearing the child) could be recovered under McFarlane supra $\mathrm{n} 7$.

52 Note, however, that this does not necessarily mean that the quantum of damages which is due to the mother (if liability is established) exceeds $£ 15,000$.

53 Not all of the judges who have denied claims for wrongful conception have normatively deemed motherhood to be a joy-some have argued that the benefits and burdens cannot be calculated.
} 
with reproductive autonomy would be remedied according to the principle of full compensation.

These are difficult questions and space constraints prevent me from attempting to answer them-any attempt to sketch answers would not do justice to the complexity of the issues. Interestingly, neither Fox (2017) in his 91-page article focusing on both imposed and denied parenthood, nor Sanger (2018) in her comment on Fox, attempted to answer these questions. I will merely make three points. The common law's animosity towards the imposition of positive duties might suggest that, as a starting point, imposed parenthood should be taken as a more serious wrong than denied parenthood. If this is accepted, the remedy in Yearworth being (seemingly) more generous than that in Rees is inconsistent with the system's basic principles and manifests androcentric bias (cf. Bernstein 2018).

However, this starting point is likely to be seriously contested, not least from some feminist strands (e.g. a certain understanding of relational feminism). West $(1988,53)$ highlights the experiential contradiction between women both valuing intimacy and dreading the intrusion and invasion which intimacy implies (while men have a similar contradiction between autonomy and alienation). This account might be the foundation upon which the answers to these questions from a feminist perspective could build.

Finally, any such answers should avoid the pitfall of adopting the existing androcentric measure in Yearworth as the anchoring point for determining the proper remedy for imposed motherhood. This goes back to both the tension on which I have commented in my previous writings between coherence and the attainment of substantive justice (Keren-Paz 2013, 2017) and, more broadly, the limits of law as a transformative, progressive tool (the 'master's tools' problem).

\section{A Comparative Perspective: ACB v Thomson Medical Pte Ltd}

Both under-theorisation and gender blindness mar the recent Singaporean decision of $A C B$. The case involved a negligent mix-up of genetic material in an IVF process; as a result, the baby daughter born had no genetic affiliation to the father and this was apparent due to her darker skin tone. The Court of Appeal approved the lower court's rejection of the claim for upkeep costs and held that injury to autonomy is not an actionable damage per se. However, 'a loss of autonomy may underlie a more specific award of damages in the context of a negligent interference with the plaintiff's reproductive plans, ${ }^{54}$ Such a loss was manifested in losing genetic affinity with the baby. Damages should be substantive and individualised (i.e. not a conventional award as in Rees); and for practical reasons, the damages could be set as a percentage of the upkeep costs. The court decided that in this case the award should be 30 percent of the upkeep cost and remanded the case for that cost to be calculated. ${ }^{55}$

\footnotetext{
54 Supra $\mathrm{n} 11$ [115].

55 Ibid [150]. The court also denied the availability of punitive damages on the facts of the case while leaving them as a rare possibility for claims in negligence.
} 
The decision is very rich and could easily be the subject of a standalone article. In what follows, I will comment very briefly on directions for future analysis and will focus on how $A C B$ compares with English decisions in terms of a consistent approach to protecting autonomy in negligence and of a gender analysis of reproductive torts. As we shall see, such evaluation would view $A C B$ as a mixed bag.

As in English cases, ITA is not fully recognised in $A C B$ as actionable damage. The reasons afforded in the decision-conceptual, coherence and over-inclusiveness objections ${ }^{56}$ - are unconvincing, and nothing in the reasoning undermines my recent conclusion (with which the court did not engage) that ITA ought to be recognised as actionable damage (Keren-Paz 2017, 425-437). But of course, not all ITAs ought to be remedied and reproductive autonomy seems to be protected in the decision, which is commendable. On the positive side, three aspects of the decision are an improvement on the decision in Rees and are in line with the critique offered above: that the award is individualised, so consistent with the principle of full compensation ${ }^{57}$; substantive, so not derisory ${ }^{58}$; and that the court appreciates that the main costs of unwanted parenthood are not pecuniary. ${ }^{59}$ This indicates that the court correctly understands undermining reproductive autonomy as a serious type 2 ITA and while the typology is not explicitly present, some of the court's analysis hints at its existence and relevance. ${ }^{60}$

On the negative side, as in English cases, there is hardly any overt appreciation that reproductive harms are gendered and that this might be relevant to the extent to which we deem the harm worthy of being actionable. ${ }^{61}$ Given the overall length of the decision-136 pages - and the depth in which other policy considerations were treated, the obliviousness to gender equality considerations is disappointing. ${ }^{62}$ Moreover, endorsing the equation of maintenance (upkeep costs) with loss of earnings (consequent on care responsibilities) ${ }^{63}$ is oblivious to the gendered nature of the latter (but less so the former) loss.

The case raises two other (and related) difficulties, which are absent in wrongful conception cases but cannot be addressed here. First, a potential critical race critique that the decision in fact views a different race (or more specifically a darker tone)

\footnotetext{
56 Ibid [115-124].

57 Ibid [141-142, 145].

58 Ibid [148].

59 Ibid $[18,107]$.

60 See in particular ibid $[122,130]$.

61 For example, the term parenthood is cited in the case more than 30 times; motherhood only once-a quotation from a previous (English) case essentialising motherhood 'unnatural rejection of womanhood and motherhood would be generously compensated'. The closest appreciation of the issue as gendered is a reference at [70] to LJ Hale's speech in Parkinson v St James and Seacroft University Hospital NHS Trust [2001] EWCA Civ 530 noting the 'consequences arising out of the unplanned pregnancy (which, as she noted, were many and varied and which she described in powerful detail)'.

62 It could be argued that selecting ITA in reproductive torts as actionable damage against the general rule disqualifying ITA as actionable damage is an example of gender sensitivity so that the gendered nature of the harm operated as a 'hidden persuader'. Even if this were true, the failure to give gender justice its proper due in the policy debate is problematic.

63 Supra n 11 [104].
} 
baby as injury ${ }^{64}$; and secondly, the limits of choice. It is one thing to accept that having an unwanted child is an injury; it is another to accept that having a child with different characteristics than you wished is. While I support an award for ITA 2 in $A C B$ as appropriate, I posit that even those disagreeing could still support a significant award of damages in wrongful conception cases.

In terms of inconsistencies, I will limit my comments to the following three (although there are more). First, some of the reasoning leading the court to reject the upkeep costs and ITA as generally actionable (even if convincing on their own terms) undermines the court's recognition of reproductive autonomy, manifested in absence of genetic affinity, as actionable. If claimants 'consciously choosing' to have genetic affiliation through IVF is a sufficient reason to hold the negligent defendant under a duty to compensate them, ${ }^{65}$ why is the conscious choice not to become a parent not a reason to compensate them for the upkeep and non-pecuniary costs (which were denied), and the interference with their autonomy (which was left as an open question) ${ }^{66}$ Or conversely, if pecuniary (and non-pecuniary) costs are irrecoverable since they are 'about the consequences to the Appellant qua mother of the existence of the child and the concomitant ... relationship ... [entailing] legal, moral, and social obligations to care for, support, and nurture ${ }^{67}$ how is it that the claim for undermining genetic affiliation, also 'qua mother', is recoverable?

Secondly, in a twist to the normative 'birth-cannot-be-a-loss' argument, the court explains that 'parental obligations' are based on a 'custodial relationship between parent and child and a relationship of trusteeship between the parents and wider society'. 'Neither of these relationships gives rise to obligations which are capable of valuation as "loss" in any meaningful sense', ${ }^{68}$ financial or care-based. ${ }^{69}$ However, the fact that a voluntary undertaking is a cornerstone condition for a fiduciary duty ${ }^{70}$ should have led the court to reject the conclusion that parental obligations 'are not capable of characterisation as a loss', ${ }^{71}$ since 'the Appellant did not, in fact, have any choice in the matter'. ${ }^{72}$ On either of the following variants of the argument, imposed parenthood ought not block parents from seeking compensation for their losses: either that imposed parenthood cannot be based on a trusteeship relationship (since it is not voluntary), or that seeking damages from the party whose negligence

\footnotetext{
64 The court (ibid at [131]-[135]) addressed this difficulty, quite convincingly in my opinion, by reference also to Sally Sheldon's analysis (2011) of the Northern Ireland case of $A$ and B by $C v A$ Health and Social Services Trust [2011] NICA 28. In $A$ and B, the claim was framed as harm due to being born with a different skin colour than the parents and was denied. Sheldon criticises 'reducing the alleged harm to irrelevant physical variation', for failing to give voice to the true harm that was suffered and ignoring the social context of likely racially based bullying of the child and questioning of the mother's fidelity (cf. McCandless (2017); and, in the US context, Fox (2017, 231-234)).

65 Supra n 11 [129].

66 Ibid [136].

67 Ibid [87].

68 Ibid [90].

69 Ibid [91-92].

70 See Bristol and West Building Society v Mothew [1998] Ch 1, 18; Finn (1977, 9).

71 Supra n 11 [90].

72 Ibid [84].
} 
created forced trusteeship does not undermine the nature of the parental obligation and is compatible with it. Indeed, it hard to see why conceptually or symbolically, let alone practically, seeking compensation from a third party is incompatible with the parent's duty to the child. In practice, such a right will only improve the parent's capacity to discharge the obligation to the child (cf. Keren-Paz 2007b, 147-148).

Thirdly, the commendable realisation that focusing 'on the financial consequences of the birth is ... inadequate ... [and] misleading ${ }^{73}$ is undermined by measuring the ITA as a percentage of upkeep costs (cf. Purshouse 2017, 15; Amirthalingam 2018, 18). Besides being conceptually arbitrary, and returning pecuniary costs to centre stage, such a rule is regressive, by extending the wealth-dependent character of upkeep costs (used as an argument against awarding them in McFarlane $)^{74}$ to ITA, and symbolically offensive, by suggesting that the value (measured by upkeep costs) of a baby with lower genetic affinity is lower than a value of a baby with full genetic affinity (this also undermining the court's insistence that the holding does not denigrate adoption ${ }^{75}$ ).

Finally, it is unclear whether the court will allow recovery for wrongful conception in which there is no undermining of genetic affinity. In terms of ITA, however, it will be odd to compensate parents who wanted a child with genetic affinity to both parents but due to negligence had a child genetically affiliated only with the mother but to refuse compensating parents who did not wish to raise a child at all (cf. Purshouse 2017, 15-16; Fox $(2017,226,231-233)$. Surely, the ITA is more significant in the latter case? (Unless, for the court, the gist of the damage was reputational i.e. the apparent lack of genetic affinity due to the difference in skin tone. ${ }^{76}$ As mentioned above, such a proposition is normatively contested).

A related difficulty is that in $A C B$ the mother received damages for lessened genetic affiliation with the baby, despite the fact that she is genetically affiliated to the baby. This raises interesting questions about privity and scope of liability (cf. Amirthalingam 2018, 20), and from a feminist perspective could be criticised as androcentric and patriarchal. The interest recognised by the law as so deserving compensation is the father's interest in genetic affiliation with the child, although this interest is dressed up as the mother's interest in having a child genetically affiliated to her husband. Moreover, symbolically, the inference that damages connote a devaluation of the specific child born seems to be stronger in wrongful fertilisation in which the parents wanted a child, but not this one, than in wrongful conception, in which the parents did not wish for a (or an additional) child at all (cf. Amirthalingam 2018, 19).

\footnotetext{
73 Ibid [107].

74 Supra 34.

75 Supra n 11 [129].

76 Ibid [131-134].
} 


\section{Conclusion}

The only English case explicitly compensating injury to autonomy as actionable in negligence is Rees, in the context of failed sterilisation. As the discussion demonstrated, however, rather than celebrating Rees as a feminist judgment, we should lament it as demonstrating gender blindness and androcentrism when examined both for itself and compared to Yearworth and Chester. To begin with, Rees was decided against the background of McFarlane, which denied upkeep costs due according to general principles, based on distributive justice considerations; in so doing, it was oblivious to the fact that gender-based distributive considerations support a substantial remedy for the gendered harm of wrongful conception. The denial of substantive remedy undermined the mother's autonomy, arguably in a discriminatory manner, by setting off, contrary to principle, deemed joys imposed on the mother (non-pecuniary benefit) against the upkeep costs (pecuniary damage). Worst still, in doing so, the court refused to legally acknowledge that unwanted motherhood is a 'detriment', mansplaining to the woman who explicitly sought not to become a mother that she is deemed to enjoy the experience.

The decision in Rees, to award damages for the significant ITA type 2 involved in becoming a mother involuntarily, could have been laudable but the following facts make Rees a Pyrrhic victory to hopefuls of gender justice in tort law: that what was awarded was (a) a conventional award deviating from the principle of full compensation, (b) a derisory amount of merely $£ 15,000$ and (c) according to Lord Millet an equal amount is due to the father.

In the broader context of Chester and Yearworth the picture only becomes gloomier. A gender-neutral type 1 ITA, which is much less serious, receives in Chester inflated type 3 remedy, while the significant gendered type 2 ITA of becoming an involuntary mother receives a lower award. Worse still, English law seems to remedy more favouringly type 2 injury to reproductive autonomy when the claimants are men, than when they are women. Mental distress from the fear of being negligently deprived from being a father is not subject to a conventional award of low value, while damages for the significant, life changing consequences of undermining a woman's autonomy by negligently thrusting motherhood upon her are capped.

From a comparative perspective, certain aspects of the $A C B$ holding are an improvement, namely, individualised and substantive award and (in theory) being appreciative that the main costs of unwanted parenthood are non-pecuniary. Beyond internal inconsistencies in the decision which were highlighted above, the reasoning is problematic from a gender justice perspective in two related aspects. First, it seems to prioritise lack of genetic affinity (having a much-wanted child, but from the wrong father) over imposed motherhood as a greater undermining of autonomy. This seems odd and representative in undermining the significance of unplanned motherhood on the claimant's ability to be the author of her life story. Secondly, the interest recognised by the law as so deserving compensation is the father's interest in genetic affiliation with the child, although this interest is 
dressed up as the mother's interest in having a child genetically affiliated to her husband. Such interest should not be looked down upon, but its remedying hardly stands as a feminist triumph, especially in the context in which a right for substantive damages for imposed motherhood is yet to be recognised.

Acknowledgements I would like to thank Nicky Priaulx and FLS anonymous reviewers and editorial board for extremely useful comments on previous drafts, and Bushra Jalil for excellent research assistance. The article was supported by a Leverhulme Fellowship RF-2016-35818 which is acknowledged with thanks.

Open Access This article is distributed under the terms of the Creative Commons Attribution 4.0 International License (http://creativecommons.org/licenses/by/4.0/), which permits unrestricted use, distribution, and reproduction in any medium, provided you give appropriate credit to the original author(s) and the source, provide a link to the Creative Commons license, and indicate if changes were made.

\section{References}

Abel, Richard. 1990. A Critique of Torts. UCLA Law Review 37: 785-830.

Althusser, Louis. 1976. Essays in Self-Criticism. Grahame Lock tr. London: New Left Books.

Amirthalingam, Kumaralingam. 2018. Reproductive Negligence: Unwanted Child or Unwanted Parenthood? Law Quarterly Review 134: 15-20.

Annas, George. 1986. Pregnant Women as Fetal Containers. Hastings Center Report 16(6): 13-14.

Bass, Brooke. 2015. Preparing for Parenthood: Gender, Aspirations and the Reproduction of Labour Market Inequality. Gender \& Society 29(3): 362-365.

Bauer, Annette, et. al. 2014. The Costs of Perinatal Mental Health Problems. Centre for Mental Health and London School of Economics.

Bernstein, Anita. 1997. Treating Sexual Harassment with Respect. Harvard Law Review 111: 445-527.

Bernstein, Anita. 2016. Common Law Fundamentals of the Right to Abortion. Buffalo Law Review 63: 1141-1210.

Bernstein, Anita. 2018. The Common Law Inside the Female Body. Cambridge: Cambridge University Press.

Biggs, et al. 2017. Women's Mental Health and Well-Being Five Years after Receiving or Being Denied an Abortion: A Prospective, Longitudinal Cohort Study. JAMA Psychology 74(2): 169-178.

Bitton, Yifat. 2010. Liability of Bias: A Comparative Study of Gender-Related Interests in Negligence Law. Annual Survey of International \& Comparative Law 16(1): 63-128.

Bordo, Susan. 2003. Are Mothers Persons? Reproductive Rights and the Politics of Subjectivity [in] Unbearable Weight: Feminism, Western Culture, and the Body, 71-98. Berkeley: UCP.

Cain, Ruth. 2007. Confessions of the New Capitalist Mother: Twenty-First-Century Writing on Motherhood as Trauma. Women: A Cultural Review 18(1): 19-40.

Cane, Peter. 1997. The Anatomy of Tort Law. Oxford: Hart Publishing.

Cane, Peter. 2004. Another Failed Sterilisation. Law Quarterly Review 120: 89-93.

Chamallas, Martha. 1998. The Architecture of Bias: Deep Structures in Tort Law. University of Pennsylvania Law Review 146: 463-531.

Chamallas, Martha, and Jennifer Wriggins. 2010. The Measure of Injury: Race, Gender, and Tort Law. New York: NYUP.

Chico, Victoria. 2011. Genomic Negligence. Oxford: Routledge.

Christman, John. 2004. Relational Autonomy, Liberal Individualism, and the Social Constitution of Selves. Philosophical Studies 117: 143-164.

Clark, Tamsyn, and Donal Nolan. 2014. A Critique of Chester v Afshar. Oxford Journal of Legal Studies 34: 659-692.

Cornell, Drucilla. 1995. The Imaginary Domain: Abortion, Pornography and Sexual Harassment. Oxford: Routledge. 
Cowan, Sharon. 2007. Choosing Freely: Theoretically Reframing the Concept of Consent. In Choice and Consent: Feminist Engagements with Law and Subjectivity, ed. Rosemary Hunter and Sharon Cowan, 91-105. Oxford: Routledge.

Dagan, Hanoch. 2013. Autonomy, Pluralism, and Contract Law Theory. Law and Contemporary Problems 76: 19-38.

Dan-Cohen, Meir. 2002. Harmful Thoughts: Essays on Law, Self, and Morality. Princeton: Princeton University Press.

Donath, Orna. 2015. Regretting Motherhood: A Sociopolitical Analysis. Signs: Journal of Women in Culture and Society 40: 343-367.

Finn, Paul. 1977. Fiduciary Obligations. Sydney: Law Books.

Fox, Dov. 2017. Reproductive Negligence. Columbia Law Review 117: 149-241.

Frankfurt, Harry. 1971. Freedom of the Will and the Concept of a Person. Journal of Philosophy 68: 5-20.

Graycar, Regina, and Jenny Morgan. 2002. The Hidden Gender of Law. 2nd ed. Sydney: The Federation Press.

Hoagland, Sarah. 1988. Lesbian Ethics: Toward New Value. Arizona: Institute of Lesbian Studies.

Hunter, Rosemary, and Sharon Cowan. 2007. Choice and Consent: Feminist Engagements with Law and Subjectivity. Oxford: Routledge.

Keating, Gregory. 2000. Distributive and Corrective Justice in the Tort Law of Accidents. South California Law Review 74: 193-224.

Keren-Paz, Tsachi. 2005. On Mothers, Babies and Bathwater: Tort Law, Distributive Justice and Prenatal Duties. Social \& Legal Studies 14(2): 179-197.

Keren-Paz, Tsachi. 2007a. Compensating Injury to Autonomy: Normative Evaluation, Recent Developments and Future Tendencies. Colman Law Review 22: 187-266.

Keren-Paz, Tsachi. 2007b. Torts, Egalitarianism and Distributive Justice. Aldershot: Ashgate.

Keren-Paz, Tsachi. 2008. Nicolette Priaulx, The Harm Paradox: Tort Law and the Unwanted Child in an Era of Choice. Feminist Legal Studies 16: 269-272.

Keren-Paz, Tsachi. 2013. Sex Trafficking: A Private Law Response. Oxford: Routledge.

Keren-Paz, Tsachi. 2017. Compensating Injury to Autonomy: A Conceptual and Normative Analysis. In Private Law in the 21st Century, ed. Kit Barker, Karen Fairweather, and Ross Grantham, 411-437. Oxford: Hart.

Keren-Paz, Tsachi. 2018. Compensating Injury to Autonomy in English Negligence Law: Inconsistent Recognition. Medical Law Review. https://doi.org/10.1093/medlaw/fwy009.

Koenig, Thomas, and Michael Rustad. 1995. His and Her Tort Reform: Gender Injustice in Disguise. Washington Law Review 70: 1-90.

Lindley, Richard. 1986. Autonomy. London: Macmillan.

MacIntyre, Alasdair. 1984. After Virtue: A Study in Moral Theory. 2nd ed. Notre Dame: University of Notre Dame Press.

McCandless, Julie. 2017. A and B by C v A (Health and Social Services Trust). In Northern/Irish Feminist Judgments: Judges' Troubles and the Gendered Politics of Identity. Oxford: Hart Publishing.

McGlynn, Clare, and Erica Rackley. 2017. Image-Based Sexual Abuse. Oxford Journal of Legal Studies 37: 534-561.

Meyers, Diane. 1987. Personal Autonomy and the Paradox of Feminine Socialization. Journal of Philosophy 84: 619-630.

Morris, Anne. 2004. Another Fine Mess: The Aftermath of McFarlane and the Decision in Rees v Darlington Memorial Hospital NHS Trust. Professional Negligence 20: 2.

Nedelsky, Jennifer. 1989. 'Reconceiving Autonomy: Sources, Thoughts and Possibilities'. Yale Journal of Law \& Feminism 1: 7-36.

Nolan, Donal. 2007. New Forms of Damage in Negligence. Modern Law Review 70: 59-88.

Nilsen, Ann, Julia Brannen, and Suzan Lewis. 2013. Transitions to Parenthood in Europe. Bristol: Policy Press.

O'Shea, Tom. 2012. Critics of Autonomy. Essex Autonomy Project. https://autonomy.essex.ac.uk/wpcontent/uploads/2016/11/CriticsofAutonomyGPRJune2012.pdf. Accessed 3 June 2018.

Oshana, Marina. 2006. Personal Autonomy in Society. Aldershot: Ashgate.

Priaulx, Nicolette. 2007. The Harm Paradox: Tort Law and an Unwanted Child in an Era of Choice. Oxford: Routledge.

Priaulx, Nicolette. 2017. Reproducing the Properties of Harms that Matter: The Normative Life of the Damage Concept in Negligence. Journal of Medical Law and Ethics 5: 17-56. 
Purshouse, Craig. 2015. Liability for Lost Autonomy in Negligence: Undermining the Coherence of Tort Law? Torts Law Journal 22: 226-249.

Purshouse, Craig. 2017. Autonomy, Affinity, and the Assessment of Damages: ACB v Thomson Medical PTE LTD [2017] SGGA 20 and Shaw v Kovac [2017] EWCA Civ 1028. Medical Law Review. https ://doi.org/10.1093/medlaw/fwx056.

Raz, Joseph. 1988. Autonomy, Toleration, and the Harm Principle. In Justifying Toleration: Conceptual and Historical Perspectives, ed. Susan Mendus, 155-175. Cambridge: Cambridge University Press.

Sanchez, Laura, and Elizabeth Thomson. 1997. Becoming Mothers and Fathers: Parenthood and the Division of Labour. Gender \& Society 11(6): 747-773.

Sanger, Carol. 2018. The Lopsided Harms of Reproductive Negligence. Columbia Law Review 18: 29-47.

Schober, Pia. 2010. The Parenthood Effect on Gender Inequality: Explaining the Change in Paid and Domestic Work When British Couples Become Parents. GeNet Working Paper No 2. pp. 1-30.

Sheldon, Sally. 2016. The Decriminalisation of Abortion: An Argument for Modernisation. Oxford Journal of Legal Studies 36: 334-365.

Siegel, Reva. 2007. Sex Equality Arguments for Reproductive Harms: Their Critical Basis and Evolving Constitutional Expression. Emory Law Journal 56: 815-842.

Thompson, Judith Jarvis. 1971. A Defense of Abortion. Philosophy \& Public Affairs 1: 47-66.

Thompson, Linda, and Alexis Walker. 1989. Gender in Families: Women and Men in Marriage, Work and Parenthood. Journal of Marriage and the Family 51: 845-864.

Varuhas, Jason. 2014. The Concept of Vindication in the Law of Torts: Rights, Interests and Damages. Oxford Journal of Legal Studies 24: 253-270.

Voorhoeve, Alex. 2009. The Limits of Autonomy. The Philosophers' Magazine 46: 78-82.

West, Robin. 1988. Jurisprudence and Gender. University of Chicago Law Review 55: 1-72.

West, Robin. 1997. Caring for Justice. New York: NYUP.

Wilcox, Vanessa. 2012. Vindicatory Damages: A Farewell? Journal on European Tort Law 3(3): 390-405. 